QUADERNS DE FILOSOFIA VOL. VII NÚM. 2 (2020): I I-33

eISSN: 234I-3042 DOI: I0.7203/QFIA. 7.2.20287

Francisco Martorell Campos*

\title{
Nueve tesis introductorias sobre la distopía
}

Nine introductory theses about dystopia

Resumen: Este artículo proporciona una introducción actualizada a la distopía y una exégesis del apogeo ilimitado que esta vive. Y lo hace planteando nueve tesis. El supuesto de partida es que el término "distopía" no designa solamente una forma literaria. Sus premisas, metodologías y actitudes elementales son visibles en el pensamiento social contemporáneo y otras muchas expresiones culturales. En las dos primeras tesis diferencio el género distópico de otros géneros afines y sondeo las coincidencias temáticas que atesoran sus expresiones literarias y filosóficas. A lo largo de las tres tesis posteriores, señalo las causas sociales e ideológicas que subyacen a su hegemonía actual. Finalmente, dedico las cuatro últimas tesis a calibrar las implicaciones políticas de la distopía y a determinar las relaciones que guarda con la utopía.

\begin{abstract}
This article provides an up-to-date introduction to dystopia and an exegesis of its huge heyday, in nine theses. The starting point is that the term "dystopia" does not designate only a literary form. Its basic premises, methodologies and attitudes are visible in contemporary social thought and many other cultural expressions. In the first two theses, I distinguish the dystopian genre from other related genres and probe the thematic coincidences among their literary and philosophical expressions. Throughout the three subsequent theses, I point out the social and ideological causes that underlie its current hegemony. Finally, I devote the last four theses to calibrating the political implications of dystopia and to determining its relationship with utopia.
\end{abstract}

Palabras clave: distopía, utopía, antiutopía, progreso, imaginación. Keywords: dystopia, utopia, anti-utopia, progress, imagination.

* Doctor en Filosofía por la Universitat de València. 
T a distopía literaria desplazó a la utopía desde inicios del siglo xx. LEn tiempos recientes, este subgénero pesimista de la ciencia ficción ha dilatado su preponderancia previa y se ha convertido en una moda de masas. El interés de dicho incidente es doble. Por una parte, nos vemos rodeados de diagnósticos de las patologías de la civilización occidental maquinados para trasladar a las personas corrientes el cuestionamiento del sistema dominante, con un contenido que traza no pocas intersecciones con los diagnósticos filosóficos. Por otra parte, y en tanto que manufactura de la industria cultural, la distopía reproduce con asiduidad las contradicciones y resortes ideológicos de ese sistema que pretende impugnar. En este trabajo encadeno nueve reflexiones sobre el género distópico que tienen por objetivo clarificar los conceptos en disputa, tantear el origen y la naturaleza de la distopización absoluta de los imaginarios presentes y controvertir algunas confusiones y simplificaciones.

Aunque toda distopía construye una representación negativa del futuro, no toda representación negativa del futuro pertenece a la distopia. A fin de evitar malentendidos, haremos memoria. Precursores al margen (Rabelais, Swift, Voltaire), la distopía irrumpió de manera oficial y definitiva a mediados del siglo XIX. La frustración experimentada ante las promesas ilustradas y los temores fustigados por la industrialización capitalista dieron pie a los ataques dispares de los románticos decimonónicos contra la Zivilisation mecanicista, urbana, cientificista e individualista que estaba sustituyendo aceleradamente a la Kultur orgánica, rural, espiritual y comunitaria. A ojos de numerosos intelectuales del momento (Dostoievski, Burckhardt, Baudelaire), la llegada de la Zivilisation condenaba a los hombres a una existencia superficial, degradada e impersonal, y a Occidente a cruzar "un proceso de deterioro, agotamiento y colapso inevitable” (Herman i 998, 17). La costumbre de tachar a las sociedades occidentales de decadentes tuvo en las facciones anti-modernas, incrédulas y/o victorianas del XIX su fuente, igual que la distopía misma, germinada entonces de la mano de Lo que será el mundo en el año 3000 (Souvestre I846), París en el siglo XX (Verne I 863), Erewhon (ButLer I872), The Age of Science; A Newspaper of the Twentieth Century (Совве I877), Erchomenon; or the Republic of Materialism (Crocker I 879) y The Inner House (Bessant i 888).

Vemos que la distopía corre, genealógica y constitutivamente, paralela a la depreciación de la civilización. El desempeño de este concurrido cometido sigue dos resoluciones cuya disociación problematizaremos luego: o el desenmas- 
caramiento de las implicaciones nocivas del utopismo, entidad que el distópico asocia con totalitarismos atroces, o la impugnación de las hegemonías y jerarquías vigentes, destellos, de acuerdo con la distopía, de una sociedad de control tentacular disfrazada de democracia. Al margen de la opción elegida, el análisis más somero acredita que los autores distópicos movilizan un único método: comparar la sociedad real con sociedades imaginarias del futuro diseñadas con el propósito expreso de que los lectores las consideren peores que, y causalmente enlazadas a, aquella donde viven (SARGENT 2006, 15), bien porque materializan los horrores inconfesados de las utopías que la retan o porque llevan hasta las últimas consecuencias lógicas sus tendencias amenazadoras (BOOKER I994, 3). Es así, pues, que el relato sobre el porvenir fatídico será distópico si y solo si transcurre en el seno de una sociedad ficticia indeseable, auténtica protagonista de la trama. Además de ello, deberá retratarla en pleno funcionamiento, cartografiarla con minuciosidad y como si de una totalidad se tratara, dedicando especial atención a los dispositivos político-tecnológicos de poder y a los mecanismos invertidos para que los individuos se plieguen a él y/o lo interioricen. La cláusula societaria de la distopía conlleva que el espacio paradigmático de la narración sea análogo al de la utopía ortodoxa, es decir, la ciudad (Mumford 1982, 31; FrYe 1982, 56), transmutada en recinto de la infamia.

Estas clausulas distinguen a la distopía de las otras dos escuelas fatalistas de la ciencia ficción con las que se la confunde: la apocalíptica (o catastrofista), versada en cataclismos de origen ecológico, biológico, tecnológico o extraterrestre que destruyen o merman nuestra sociedad: y la post-apocalíptica, versada en la brutal guerra de todos contra todos y la lucha despiadada por la supervivencia desatadas tras el hundimiento, cercano o remoto, de la misma. Obviamente, abordamos demarcaciones porosas, pobladas de híbridos y mestizajes. Empero, señalizan la presencia de fronteras que el rigor aconseja atender, por muy inestables que sean.

La distopía no se limita a la literatura y el cine. Al igual que la "narrativa utópica" cohabita junto a la "teoría utópica", la "narrativa distópica" cohabita junto a la "teoría distópica”. Las ventajas pedagógicas de la imagen sobre el concepto se hacen palpables en sendos enclaves. Las utopías Mirando hacia atrás (Bellamy i 887) y ¿Qué hacer? (Chernyshevski i 863) contribuyeron a divulgar los ideales socialistas en Estados Unidos y Rusia en mucha mayor medida que El manifiesto comunista. De igual modo, "ninguna teoría surgida de los totalitarismos, ni ninguna escrupulosa advertencia sobre la arrogancia 
científica o el terror tecnológico, han calado tan profundamente en el imaginario colectivo del siglo xx como lo hicieron 1984 de Orwell o Un mundo feliz de Huxley" (Kumar 2007, 73). ${ }^{1}$ Testada desde este marco de referencia, la narrativa distópica se asemeja a la versión para todos los públicos de la Dialéctica de la Ilustración, El hombre unidimensional o Vigilar y castigar. Y al revés, la teoría distópica a la versión para eruditos de Un mundo feliz, La chica mecánica (BACIGALUPI 2009) y similares.

Contemplemos un par de bifurcaciones temáticas entre lo narrativo y lo teórico.

La estampa recurrente de la distopía literaria y cinematográfica, un futuro inhumano rendido a la planificación, la propaganda y la monitorización mayúsculas, refuta, no descubro nada, la fe en el progreso. El ilustrado albergaba la certeza de que "las generaciones últimas gozarán la dicha de habitar en la mansión que toda una serie de antepasados, que no la disfrutará, ha preparado sin pensar en ello" (KANT I992, 45). La distopía acepta la casuística iluminista entre el presente y el futuro, pero invierte el decorado, lo ornamenta de pesimismo secular y alerta de que, si no cambian las tornas, las generaciones futuras no habitarán mansión alguna, sino un presidio fraguado por nuestra indolencia e insensatez. Salta a la vista que la distopía ejercita la "heurística del temor" (Jonas I994, 65-6, 76) con miras a responsabilizar a la audiencia y conferirle el deber moral de cuidar de los descendientes lejanos e impedir el porvenir catastrófico. En contraste con la utopía, la distopía denuncia qué está mal barruntando un mañana injusto acorde con ello que hemos de evitar (Fraser 20 i2, 45). Adjuntas al pensamiento negativo, estas tácticas albergan un conato optimista: "aunque las imágenes del futuro presentadas en la distopía pueden conducir hacia la desesperación", sus autores "esperan una reacción positiva por parte de sus lectores", que se tomen en serio el ultimátum y eviten la plasmación del futuro relatado (VIEIRA 20 Io, 17). La distopía sería inviable sin la creencia - muy confiada diría yo- de que una advertencia a tiempo alentará propósitos de enmienda. Su crítica al progreso (o al progreso según se ha realizado) opera, en consecuencia, al margen de la filosofía invertida de la historia, según la cual la decadencia es un proceso necesario e irreversible.

Paralelamente, la índole racionalizada, y a menudo cientificista, atribuida por la distopía al futuro advierte de los peligros inherentes a la racionalidad instrumental, facultad regida por la lógica del cálculo y la eficiencia, orientada

${ }^{1}$ Keith Booker dedica The Dystopian Impulse in Modern Literature a sondear el diálogo mantenido por la narrativa distópica y la teoría distópica. La tesis de partida es que la ficción distópica "se parece a los proyectos de críticos sociales y culturales como Nietzsche, Freud, Bakhtin, Adorno, Foucault, Habermas y muchos otros" (I994, 19). Fredric Jameson cataloga a la filosofía de Adorno, Horkheimer, Debord y Baudrillard de distópica en Arqueologías del futuro (2009, 191), y hace lo propio con la filosofía de Foucault en An American Utopia (2017, 2). 
al dominio implacable de la naturaleza. Filósofos de muy variada condición, desde Weber pasando por Spengler, Wittgenstein, Husserl, Heidegger, Jaspers, Anders, Adorno, Marcuse, Elias o Byung-Chul Han, se han dedicado a repetir que la modernidad redujo el significado de "razón" al de ese tipo de racionalidad, autora de los grandes avances científicos cosechados en el orden natural. Deseosa de lograr avances análogos en el orden social, cometió el error de aplicarla al ámbito político, ergo más allá de su territorio legítimo de actuación, artimaña que comportó la extrapolación de la voluntad de dominio, cálculo y eficiencia a la propia humanidad, devenida, a la postre, en objeto a administrar, manipular y cuantificar. Lejos de restringirse a la alta cultura, esta teoría de la racionalidad comparece de manera ostentosa en las distopías narrativas, prestas a exponer cómo "en la medida en que va cumpliendo cada vez de modo más perfecto su programa, y por lo tanto no por error, accidente o distracción casual, la racionalización del mundo se vuelve contra la razón y contra sus fines de perfeccionamiento y emancipación" (VATTimo I 996, 97). ${ }^{2}$

No obstante las equivalencias, hay, ciertamente, disimilitudes entre los sectores narrativos y teóricos de la distopía. Y no me refiero al hecho de que la teoría distópica discurra acerca del presente y no del futuro. A fin de cuentas, la imagen de la actualidad resultante de su quehacer plasma un mundo peor de lo que piensa el común de los mortales, en ocasiones salpicado de pinceladas del mañana calamitoso. Las disimilitudes a inspeccionar conciernen a los contenidos e involucran a facciones específicas. Por ejemplo, los pensadores distópicos de perfil progresista, urbano y/o vanguardista menosprecian las proclamas de muchos novelistas distópicos a favor del individuo autosuficiente, la vida rural y la búsqueda de autenticidad, amén de supuestos como el de que las humanidades sanan la cosificación e interrumpen el compás mecanicista del Leviatán. ${ }^{3}$ Aún así, merecen el rótulo

\footnotetext{
${ }^{2}$ Vattimo añade a continuación que lo manifestado en la distopía "se puede entender como un salir a la luz de la contrafinalidad de la razón; de eso que en otros términos, Horkheimer y Adorno, en su libro de 1947, han llamado Dialéctica de la Ilustración” (Ibid.). Andreu Domingo mantiene que la distopía exhibe al gran público "el retrato de los monstruos engendrados por la razón” $(2008,15)$. En la novela distópica El hombre que despertó en el futuro, publicada por entregas en 1933, Norman Winters, el protagonista, visita el ańo 10.000, fecha donde la civilización es gobernada a golpe de lógica pura por "El Cerebro", máquina pensante entregada a la opulencia, asueto y felicidad de los humanos. Uno de los nativos espeta: "El Gran Cerebro es infalible. ¿Quién querría actuar en forma contraria a la razón?” (Manning I976, 84).

${ }^{3}$ A este respecto, resultan imprescindibles las lecturas que Adorno y Horkheimer realizaron de Un mundo feliz. Sendos autores aceptan la pericia de Huxley a la hora de detectar los extravíos de la racionalización, si bien oponiéndose a los remedios que, según ellos, insinúa entre líneas. Véase: Adorno (2008, 85-107) y Horkheimer (2002, 86-7). El rechazo de Adorno y Horkheimer de la concepción romántica de la naturaleza publicitada por Un mundo feliz evoca al rechazo de Zizek del concepto platónico-dualista de la realidad publicitado por Matrix (Zizek 2006, 175-205).
} 
de distópicos porque participan de las equivalencias nombradas y reproducen el gesto arquetípico de la distopía, a saber: brindar meticulosos diagnósticos de las patologías civilizatorias exentos de propuestas de mejora o superación.

\section{III}

El superávit de distopias y el déficit de utopias experimentados actualmente no conforman un fenómeno nuevo. Si nos ceñimos a la esfera literaria, es manifiesto que el auge de la distopía empezó a cocinarse antes, tras la Primera Guerra Mundial (Trousson i 995, 311) y los indicios de degeneración del comunismo soviético, eventos que, unidos a la Gran Depresión, dilataron en la década de los treinta el influjo del pesimismo cultural y la cantidad de publicaciones distópicas. Al terminar la Segunda Guerra Mundial, y con los totalitarismos, las bombas atómicas, los genocidios, el Gulag y la violencia de Estado ocupando el primer plano de la discusión, ya era la distopía la que acaparaba el estrellato, no la utopía, cuyas presencias editoriales descendieron hasta mínimos históricos, sin rozar nunca la tremenda resonancia obtenida en su día por las utopías de Edward Bellamy, William Morris, Étienne Cabet o H. G. Wells (Kumar 20i o, 555-8).

La consolidación gradual de la distopofilia prosiguió su marcha triunfal, inclusive en el lapso 1974-1976, cuando el feminismo, el ecologismo y la contracultura espolearon la escritura de Los desposeidos (Le GuIn I974), Ecotopía (Callenbach 1975), El hombre hembra (Russ 1975) y Mujer al borde del tiempo (Piercy 1976), utopías cruciales para la renovación del género. Las distopías ganaron cuantitativa y cualitativamente por goleada en idénticas fechas, con la energía atómica, la superpoblación, la ingeniería genética, el agotamiento de los recursos y el DDT inspirando toda suerte de siniestros vaticinios (MADdox 1974). El giro distópico de la imaginación prospectiva era tan incontrovertible que los principales teóricos de la ciencia ficción le dedicaron libros específicos. ${ }^{4}$ Mientras, a la chita callando, el capitalismo global daba los primeros balbuceos y facilitaba, auxiliado por las incipientes tecnologías informáticas, el salto de los mercados nacionales al mercado global, de la economía industrial a la economía financiera, de la socialdemocracia al neoliberalismo, de la rigidez a la flexibilidad, canjes que fraguaron el tránsito de la modernidad a la postmodernidad (HARVEY 2004, 157-85).

${ }^{4}$ Véase: Amis (1960), Walsh (I96I), Hillegas (I967), Lundway (1971) y Berger (1976). 
Siendo incuestionable que la victoria de la distopia sobre la utopia lleva cien años produciéndose, resulta igualmente cierto que el esplendor distópico actualmente imperante tiene elementos diferenciales. Por de pronto, enumeraremos tres. El primero es que por muchas oleadas distópicas que hayan acaecido en el pasado, ninguna sedujo a los círculos mainstream con tanta pujanza. El volumen de títulos publicados, premios recibidos, beneficios obtenidos y audiencias recabadas carece de precedentes. Históricamente agraciada con éxitos puntuales, la distopía es hoy un género de masas, inclusive una moda juvenil. Hasta hace poco, paso al segundo elemento, el género distópico se limitaba a participar del paradigma crítico movilizado por los intelectuales y escritores taciturnos especializados en sacar los colores a la civilización occidental. Hoy sus códigos hermenéuticos catalizan, junto a otros actores secundarios, el abatido espíritu de la época y la manera cotidiana de experimentar el mundo. Cualquier hijo de vecino cree habitar una distopía.

Relacionado con los dos mencionados, interviene el tercer elemento diferencial: la preponderancia circundante de la distopía confluye con la ausencia de alternativas al capitalismo y con la incapacidad, individual y colectiva, de imaginar futuros deseables en los que no rija (Jameson 2000, 11; Harvey 20I 2, 190-1; Fisher 20I6, 27-9). Jamás había sucedido nada igual. Cuando la distopía prosperaba sobre las calamidades del siglo xx, había una alternativa oficial al modelo capitalista (no importa lo frustrante que fuera) y abundantes imaginarios políticamente radicales sobre el porvenir. Durante los sesenta y setenta, recuérdese, surgieron el freudomarxismo, la Internacional Situacionista y corrientes existencialistas tardías que mantuvieron encendida la llama de la teoría utópica. Los movimientos contraculturales adyacentes al sesentayochismo, las revueltas juveniles sobrevenidas en numerosos países, los grupúsculos hippies, el Nuevo Urbanismo, los kibutz israelíes y las comunidades experimentales del más heteróclito temperamento practicaron la política utópica (KumAR 2000, 262-8). Tales referencias atestiguan que pese a encontrarse de capa caída en la esfera literaria, la utopía continuaba operativa en las esferas filosóficas y políticas.

Habrá quienes repliquen que las protestas alterglobalización (con el eslogan, utópico donde los haya, "Otro mundo es posible") heredadas por Occupy Wall Street y el 15-M revelan, junto a la Primavera Árabe, que todavía persiste la utopía política. Y es cierto, pero precarizada. Y digo precarizada porque ninguna de las movilizaciones mencionadas blandió lo que sustancia a la utopía propiamente dicha, esto es, alternativas globales y unitarias a lo dado, dotadas de la facultad de articularse entre sí, imprimir transformaciones a gran escala 
y componer programas orientados al largo plazo. Sus brillantes querellas no se vieron complementadas con la formulación de medidas consistentes de cambio, salvo cuatro sugerencias vagas. Replicaron el modus operandi de la distopía.

La aparición del neoliberalismo y del capitalismo global cortocircuitó la comparecencia regular de enunciaciones utópicas. Convenientemente publicitada por el establishment, la caída del Muro de Berlín propició que la consigna "no hay alternativa" modelara la conciencia colectiva, pormenor que sirvió de preámbulo al siglo xxI, surgido, a diferencia de los tres anteriores, del eclipse general de la utopía política y de la consiguiente abolición de las alteridades futuras (Traverso 2019, 31). Educadas en el regazo de dicho episodio, las generaciones más jóvenes no perciben, por término medio, nada inquietante en la falta de alternativas. Jamás han conocido ninguna. Que el libre mercado sea el único modo de organización político-económica en vigor les parece algo aproblemático, dado por sentado. A sus ojos, el capitalismo resulta igual de natural que la ley de la gravedad o la salida diaria del sol. Constituye el horizonte de sentido, de lo pensable e imaginable, la condición ontológica de posibilidad (Fisher 20I6, 30). Ni que decir tiene que la cosmovisión millennial ha terminado absorbiéndonos a todos.

\section{V}

De lo expuesto se deduce que los reveses recientes no explican por sí solos la propagación masiva de la distopía. La interpretación estándar defiende que el actual apogeo distópico obedece a la intensificación del miedo motivada por los atentados terroristas de 2001 y la crisis económica internacional de 2008. Con los números en la mano, es indiscutible que la metamorfosis de la distopía en moda se produjo a partir de los lances indicados, y que el miedo, que ya venía medrando de manera mayúscula desde los albores de la postmodernidad, aumentó colectivamente más si cabe a raíz de ellos, hasta el punto de erigirse en el "constituyente básico de la subjetividad actual" (ZizeK 2009, 56), en "el más siniestro de los múltiples demonios que anidan en las sociedades abiertas de nuestra época” (BAUMAN 20IO, 166). La confluencia orquestada por el cambio climático, el auge de la extrema derecha, la pandemia de Covid-19, el agotamiento de los recursos, el aumento de la desigualdad, el terrorismo islamista, el poder de las corporaciones, la destrucción del Estado de Bienestar y la precarización laboral lo aúpa a la categoría de turbación omnipresente, cualidad que transfiere a las sensaciones de riesgo, inseguridad y vulnerabilidad que lo escoltan. El resultante no es otro que la irrupción de una cultura tremendista y atemorizada, repleta de instantáneas agoreras del mañana, anclada 
a la "fascinación por el apocalipsis" (GARCÉs 20 I 8, 15). Apocalipsis, por cierto, que difiere de los tradicionales al sobredimensionar el papel del fin y cancelar la expectativa mesiánica de que tras el correctivo impartido por la hecatombe venidera los supervivientes obtendrán la recompensa de gestionar, purgados de las perversiones pretéritas, un nuevo principio (KumAR I998, 237-43).

Supuestamente, la ubicuidad coronada por la distopía refleja la ubicuidad coronada por el miedo, su principal detonante. No obstante, si recurrimos a la historia divisaremos las grietas de este parentesco. Seamos serios. ¿o moraron tiempos oscuros las generaciones que sufrieron la pandemia de 19181919, el crack de 1929 y la constelación de catástrofes que acompañaron a, o se derivaron de, las dos Guerras Mundiales? ¿No subsistió la utopía pese a que tales calamidades fueron tan dramáticas como las que digerimos ahora? El pasado enseńa que aunque los miedos y shocks sociales sirven de coartada y trampolín a la distopía, no bastan para engendrar el absolutismo distópico. Para que la distopía adquiera total potestad hace falta el concurso inexcusable de la variable que ya conocemos, la incapacidad de imaginar alternativas ilusionantes al sistema actual, trastorno sincronizado con el descrédito de la noción de progreso (en sentido social, más que tecnológico), ${ }^{5}$ la estigmatización de lo colectivo y la mundialización, material e ideológica, del capitalismo. ${ }^{6}$

\section{VI}

La distopía se transforma en utopía, y viceversa. Eso ocurre, en el flanco de la utopía, porque las diferencias axiológicas abiertas entre el horizonte de

\footnotetext{
${ }^{5}$ Ahí está la tecnoutopía transhumanista, a la que no le afecta la deconstrucción de la idea de progreso, consumada en los acontecimientos de 1989 y vertida, desde entonces, contra cualquier noción social del mismo, no importa lo alejada que esté de la desprestigiada filosofía teleológica de la historia perpetrada por la modernidad. El transhumanismo obliga a puntualizar que el eclipse de la utopía que estamos explorando atañe, específicamente, a la utopía política. La tecnológica sigue activa, confrontándose a las no menos boyantes tecnodistopías.

${ }^{6}$ La tesis de que la acumulación de desastres no motiva por sí sola el monopolio de la distopía sale reforzada si reparamos en que la esperanza social y la utopía política eclosionan, a menudo, durante los instantes menos efusivos, sobrevolando contextos desesperados, colmados de terror y angustia. Dos muestras célebres. Condorcet firmó Bosquejo de un cuadro histórico del progreso en el peor momento de su vida, mientras huía de la persecución jacobina. Ernst Bloch escribió El principio esperanza durante su exilio estadounidense, mientras recibía de primera mano información de la barbarie nazi. Uno y otro ejemplifican que "solo si nos parece que nuestra situación es crítica vemos la necesidad de transformarla" (EAGLETON 20I6, 20). Habría que preguntarse por qué en el contexto presente, donde el miedo y la inseguridad campan a sus anchas, no despunta dicha necesidad. La respuesta, que desborda la naturaleza de este trabajo, nos llevaría de vuelta a la incapacidad de imaginar civilizaciones futuras mejores que la presente. $Y$ a otro componente ideológico de igual calado: la incapacidad, asimismo inducida, de desear y considerar factibles civilizaciones distintas.
} 
expectativas de la novela y el de los sujetos que la leen con muchas décadas de retraso provocan que estos valoren en términos distópicos lo originariamente concebido como utópico. De ahí que el grueso de utopías literarias editadas antes de la década de los setenta del pasado siglo describan sociedades que desde la óptica contemporánea "sólo querría habitar un masoquista vocacional" (EAGLeton 20io, 54). En cuantiosas ocasiones, la conmutación de la utopía en distopía prospera en el mismo contexto de producción de la obra a resultas de simples desavenencias axiológicas. Tal fue el caso, valga el precedente, de $L a$ República de Platón, distopizada por Aristóteles en el Libro II de la Política. Sin olvidar a Stuart Mill, quien declaró ante la Cámara de los Comunes que las sociedades presumiblemente perfectas divulgadas por los utópicos son, en verdad, distópicas (AlDRidge 1984, 8). Figura de referencia en todos estos asuntos, Lyman Tower Sargent leyó recién editada Walden Dos (SKinner I948) y la juzgó al instante de distopía (SARGENT 20I3, 11). El cientificismo colectivista de Hombres como dioses (Wells 1923) le causó tal desazón a Aldous Huxley que escribió Un mundo feliz a modo de catarsis. William Morris exorcizó el fastidio que le causó el socialismo industrial de Mirando hacia atrás (Bellamy I 888) redactando una utopía socialista campestre, Noticias de ninguna parte (1890). Samuel Delany confrontó su tecnoutopía Tritón (1976) a la utopía de la escasez de Los desposeídos (Le Guin 1974). Úrsula Le Guin sostuvo durante una entrevista en 2007 que la utopía marciana de Kim Stanley Robinson (1992-1996) es una distopía. ${ }^{7}$

Que la utopía de un individuo pueda ser la distopía de otro es un suceso de sencilla confirmación. ${ }^{8}$ Lo deseable es extremadamente relativo y mutable. Pero, ¿̇sucede lo opuesto? A priori no debería. A fin de cuentas, ¿quién en sus trece abrigaría deseos de habitar los regímenes de Nosotros (Zamiatin 1924), 1984 (ORwell 1949), Barra siniestra (Nabokov 1947) o El cuento de la criada (Atwood 1985)? Aun cuando la contestación se antoja obvia debido al amplio consenso que suscita en condiciones normales lo indeseable, evitemos precipitarnos, pues es más pantanosa y compleja de lo que aparenta. ¿¿Acaso no

${ }^{7}$ Jameson analiza estos intercambios de golpes entre utopistas (2009, 179 y ss). Morton reproduce casi por entero la crítica de Morris a Bellamy, publicada el 22 de enero de 1889 (I970, 155-7).

${ }^{8}$ Cioran generalizó esta ambivalencia al conjunto de utopías: "Los sueños de la utopía se han realizado en su mayor parte, pero con un espíritu muy distinto a cómo fueron concebidos; lo que para la utopía era perfección, para nosotros resultó tara; sus quimeras son nuestras desgracias. El tipo de sociedad que la utopía imagina con un tono lírico, nos parece intolerable" (I98 I, 80-1). Las distopías literarias dirigidas contra la utopía reproducen el veredicto de Cioran. Todas ellas acaecen en sociedades idénticas a las utópicas. Si su contenido coincide con el de las utopías a las que atacan, ¿qué cambia? Cambian "los juicios de apreciación del sujeto del discurso, no los contenidos de la trama” (LAdeveze 1985, 47). A menudo, la distopía canónica no es más que una utopía relatada desde el prisma del disidente. 
existen personas que desearían vivir en países que, siguiendo la moda al uso, tildaríamos de distópicos? ¿O personas que ya viven en ellos y se sienten, cítense las razones que se prefieran, dichosas de hacerlo? Si nos trasladamos al plano literario, las "distopías puritanas" —especializadas en acusar de decadentes, deshumanizados y antinaturales a futuros hedonistas, dedicados al cultivo del ocio ininterrumpido, a la estimulación del placer carnal y a la eliminación integral del sufrimiento mediante procedimientos técnicos— sí son susceptibles de insuflar en ciertos lectores, y por los mismos motivos citados a cuenta de la utopía, deseos de habitarlas. Un mundo feliz fue la utopía de cuantiosos integrantes de la contracultura californiana de los sesenta y setenta, propensos a la ingesta de sucedáneos del "soma". La recepción utópica de la novela de Huxley reapareció a través de Bruno, protagonista de Las partículas elementales. Su diagnóstico desgrana con tino el Zeitgeist de nuestros días, atravesado, de parte a parte, por malestares narcisistas y esperanzas transhumanistas concernientes a la edad, la seducción y la salud:

En el mundo que describe Huxley, los hombres de sesenta ańos tienen el mismo aspecto físico, los mismos deseos, y llevan a cabo las mismas actividades que los hombres de veinte ańos. Después, cuando ya no es posible luchar contra el envejecimiento, uno desaparece gracias a una eutanasia libremente consentida; con mucha discreción, muy deprisa, sin dramas. La sociedad que describe Brave New World es una sociedad feliz, de la que han desaparecido la tragedia y los sentimientos violentos. Hay total libertad sexual, no hay ningún obstáculo para la alegría y el placer. Quedan algunos momentos de tristeza y duda; pero se pueden tratar fácilmente con ayuda de fármacos... Es exactamente el mundo al que aspiramos actualmente, el mundo en el que desearíamos vivir (HouelLebecQ 200I, $157-8)^{9}$

La distopía no excluye la utopía ni es necesariamente su contrario. Hasta hace escasas décadas, el término que nombraba al género narrativo que ahora denominamos "distopía" era el de "antiutopía" (unos pocos preferían el de "utopía negativa", "contrautopía" o "distopía”). Los estudios practicados desde inicios de los ochenta, coincidentes con la profesionalización de los Utopian Studies, fueron revelando que ese "anti" no se correspondía con la tesitura ambigua construida por abundantes textos, motivo que provocó que la noción de

${ }^{9}$ Luisgé Martín ofrece la versión más actual y pormenorizada de idéntico parecer en su ensayo El mundo feliz. Una apología de la vida falsa (2018). 
"antiutopía" entrara en desuso (a consignar, en el mejor de los casos, un tipo de obras más específico aún) y que la noción de distopía se impusiera gradualmente en los años sucesivos.

Amén de la consabida convivencia no intencional (el hecho de que cada texto utópico contiene de manera implícita una distopía potencial y cada texto distópico una posible sociedad ideal, obra y gracia del desenmascaramiento, reformulación o negación del mañana descrito), lo utópico y lo distópico pueden coexistir de manera orgánica y deliberada. Léase si no La costa dorada (Robinson 1988), La parábola del pescador (ButLer 1994) y He, She and it (PierCy I99I), distopías producidas en los períodos tempranos de la hegemonía neoliberal, desarrolladas en futuros capitalistas extremadamente crueles, invivibles y estratificados. Pues bien, ni formulan el conflicto narrativo según las directrices clásicas, rastreando las peripecias de individuos solitarios que desobedecen al sistema sin tener opciones de politizar, no digamos ya de universalizar, su descontento, ni concluyen a la manera acostumbrada, con la derrota y liquidación de la parte fragmentada del Todo. En lugar de ello, dan la voz cantante a colectivos de oposición deseosos de derrotar al sistema, sitos, es otra peculiaridad, en zonas liberadas, ocultas a los ojos vigilantes del Leviatán. Si a esto le sumamos que escenifican revoluciones populares y que apuestan por finales abiertos, resulta evidente que estamos ante distopías sui generis que atenúan la irremediable intervención del miedo administrando pequeñas dosis de esperanza e impulsos utópicos, distanciándose del derrotismo históricamente achacado al género. Tales obras, precedidas por las aportaciones pioneras de $\mathrm{La}$ máquina se para (Forster 1904) y Mercaderes del espacio (Pohl y Kornbluth I954), plagadas de anotaciones antiautoritarias y autorreflexivas, encabezan el subgénero, hoy en boga, de la "distopía crítica" (Moylan 2000; Moylan y BACCOLINI 2003; SEYFERTH 2018), escuela que ha redimensionado las demarcaciones heredadas y abducido a infinidad de especialistas. ${ }^{10}$

Los teóricos de la distopía crítica consideran indispensable superar la antinomia utopía-distopía y atender a las complejísimas interacciones que protagonizan los dos polos. A su entender, urge diferenciar, antes que nada,

${ }^{10}$ La distopía crítica forma dueto con un género, proclive asimismo a la autorreflexividad y el antiautoritarismo, que le precedió dos lustros: la "utopía crítica", nomenclatura acuñada también por Moylan (I986) que comprende a las sociedades futuras que, aún siendo mejores que la nuestra en aspectos cruciales, arrastran sus propias contradicciones e injusticias. Frente a la sociedad perfecta agitada por el utopismo clásico (una sociedad estática, cerrada, monocolor y completamente armoniosa), la utopía crítica imagina sociedades extrańas al ideal de perfección y aliadas con el cambio, la falibilidad, la vacilación, el pluralismo y la discordia. La utopía crítica más conocida es, por méritos propios, Los desposeidos, sin olvidar al resto de utopías contraculturales de mediados de los setenta citadas en la tesis III. Las novelas utópicas de Kim Stanley Robinson son la expresión reciente de este criticismo. 
a la distopía de la antiutopía (Moylan 2000, 122; Balasopoulos 2006, 63). La primera engloba a los textos cuyos terribles porvenires manan, en última instancia, del orden capitalista imperante, mientras que los mundos futuros de la segunda provienen de la realización práctica de los proyectos revolucionarios. Si aceptamos esta disimilitud, queda claro que La República del futuro (Dodd i 887), El amo del mundo (Benson 1907), Imágenes de un futuro socialista (Richter i 89I), El Napoleón de Notting Hill (CHesterton I904), ;Vivir! (RAND I938) y 1985 (Burgess I978) personifican la "antiutopía narrativa". Ensayos de la talla de Reflexiones sobre la Revolución francesa (BURKE I790), Camino de servidumbre (HAYEK I 944), La sociedad abierta y sus enemigos (Popper 1945), El fuste torcido de la humanidad (BerLin 1990) y El fin de la historia y el último hombre (Funuyama I992) serían representativos de la "antiutopía teórica". ${ }^{11}$ El corolario al que llegan los afines a la distopía crítica es que lo contrario de la utopía no es la distopía, sino la antiutopía.

Sin demérito de su utilidad e interés, las lindes sugeridas despiertan múltiples interrogantes. Verbigracia, ¿dónde ubicamos a $1984 ?^{12}$ ¿Y a $L a$ condición postmoderna? Más aún: ¿realmente se encuentran libres de impulsos utópicos los relatos o ensayos etiquetados de antiutópicos? ¿Es asequible el grado cero de utopicidad, la sintonía, satisfacción y reconciliación terminante con lo dado? La posibilidad de que la condena taxativa al pensamiento utópico abrigue ideas utópicas subrepticias no es descabellada. Si nos fijamos, los autoproclamados antiutópicos de ayer y de hoy — consagrados a idealizar el capitalismo y a satanizar las alternativas mediante la acusación políticoantropológica (y de raigambre esencialista) de que "conducen inevitablemente a la violencia y encajan la naturaleza humana en un molde antinatural" (JAMESON 20 I6, 41-2) - blanden un "extremismo utopista camuflado", "la utopía de una sociedad sin utopías", la certeza de que "quien destruye la utopía, la realiza”. Los que juzguen que el vocablo "utopía antiutópica" peca de artificioso deberían pensar en los discursos antiutópicos del neoliberalismo, dispositivos retóricos

${ }^{11}$ El listado de filósofos antiutópicos debería reservar una entrada a Ortega y Gasset. En la sección "Antiutopismo o antirracionalismo", apéndice de El tema de nuestro tiempo, Ortega realiza una maniobra pareja a la desempeńada, con mayor amplitud, por Popper y Berlin: adherir la utopía a una epistemología racionalista, metafísica y absolutista que reprime la heterogeneidad interpretativa y el disenso. Epistemología, vienen a decir, atiborrada de implicaciones totalitarias que tendría en Sócrates su fundador, en Hegel su consumación y en la creencia en la verdad única y universal su dogma (I975, 149-54). Richard Rorty desafió al antiutopismo componiendo un modelo utópico izado, precisamente, sobre el rechazo categórico de dicha epistemología y la asunción de la contingencia, el pluralismo, la finitud y el contextualismo (1997). Al igual que los autores de utopías críticas, Rorty no dedujo de los males de la utopía tradicional la conveniencia de escribir distopías o antiutopías, sino el deber de escribir utopías distintas.

${ }^{12}$ Moylan $(2000,162)$ y Jameson $(2009,242-4)$ colocan a Orwell en el bando antiutópico. Andrew Milner (2006) disiente. 
que trascienden la celebración de lo existente y catalizan la esperanza en una civilización del porvenir distinta a la actual, plenamente mercantilizada, desregularizada y desestatalizada, ligada a "un proceso de mercado total que tiene una dimensión infinita hacia el futuro" (Hinkelammert 2002, 9-10, 278-9). Frecuentemente, quien enuncia que no le interesa la política se halla a merced de las peores políticas. Algo similar ocurre en el campo utópico. El enterrador de utopías ondea, por acción u omisión, una utopía secreta, obsesionada en camuflar su catadura. Ese gesto le delata (ZizeK 20 I I, 9, 45, 90 2) ${ }^{13}$ En ocasiones, la utopía del antiutópico no es secreta siquiera. El ataque de ¡Vivir! al colectivismo mantiene una relación directamente proporcional con la defensa del individualismo radical, ideal que jamás ha trascendido la condición de anhelo y modulado, tal cual lo bosquejó Ayn Rand, sociedad alguna.

\section{VIII}

La distopía es politicamente transversal. Acabamos de argumentar que la distinción tajante entre distopía y antiutopía presupone una acepción muy cuestionable de esta última. Da la impresión de que los teóricos que la divulgan buscan colocar en estantes distintos a las obras, dependiendo de si son progresistas o conservadoras. Las primeras, arguyen, cuestionan el presente, alientan el activismo y espolean la sed de cambios: las segundas legitiman el presente, alientan la resignación y espolean la sed de que nada cambie (BACCOLINI 2004). Es dudoso que exista una cantidad significativa de títulos donde prevalezca, nítida y unívocamente, una de tamañas dinámicas. Diríase que la mayoría las solapan en diversas gradaciones. Un mundo feliz, valga la muestra, responsabiliza con la mano izquierda al presente de engendrar la deshumanización del siglo XXvi, mientras que con la derecha lo vuelve preferible por comparación (Cotarelo 1984, 110). ¿No ocurre algo aproximado en Farenheit 451 (Bradbury 1953), El cuento de la criada y Los juegos del hambre (Collins 2008)? Emblema de la antiutopía cristiana, El amo del mundo tendría, en virtud de las definiciones alegadas, que utopizar al presente, época disconforme con el porvenir materialista y tecnólatra que extermina a cada creyente del planeta. No cabe duda de que lo utopiza en cierto sentido, si bien depreciándolo en otro, ya que le imputa los cargos de abandonar la fe, arrodillarse frente a las

${ }^{13}$ Ernst Bloch tampoco cayó en la trampa de asumir sin más la imagen antiutópica que los visionarios del capitalismo irradian de sí mismos. Escrutando la teoría smithiana de la mano invisible, Bloch descubrió un enfoque de la economía capitalista "tan prolijo como utópico" $(2004,189)$. Harvey indaga el "utopismo espacio-temporal del internacionalismo estadounidense" y del "utopismo degenerado del neoliberalismo" (201 2, 222, 225). 
idolatrías ilustradas y preparar la llegada del Anticristo. En este caso, el estado real de cosas tampoco coincide con el deseo. ${ }^{14}$

Lo dicho no es óbice para reconocer, conforme aseveró la tesis I, que las distopías se dividen, a grandes rasgos, entre las que critican el presente y las que critican las políticas de cambio radical. Sin embargo, hemos apuntado que las adversarias de la actualidad terminan justificándola involuntariamente. Y que las adversarias del utopismo no se privan de cuestionarla apelando a mundos distintos, incidencia que revela la inconsistencia del "anti" de "antiutopía". Las razones aducidas invitan a sopesar que quizá lo más clarificador sea relativizar la disyunción distopía-antiutopía, centrar la discusión en torno a lo distópico y hablar, pongamos por caso, de "distopías anticapitalistas" y "distopías antisocialistas", y dentro de estas de distopías críticas y distopías clásicas (o precríticas), a sabiendas de que algunos textos asumen formas mixtas.

La relevancia y buena reputación de la distopía crítica va unida a la profusión de distopías feministas, ecologistas y anticapitalistas. A consecuencia de ello, el género distópico parece haberse escorado claramente hacia la izquierda. Pero un par de matices ayudarán a no perder la perspectiva, a recordar que la distopía es susceptible de ser instrumentalizada por todas las ideologías políticas. Los atuendos de El cuento de la criada asoman repetidamente en las movilizaciones feministas. La exitosa, y más que notable, adaptación televisiva de la novela de Atwood ha conferido a las mujeres combativas iconos muy poderosos de la opresión patriarcal e imágenes inspiradoras de resistencia y oposición ante la inmundicia. De paso, ha avivado la publicación de centenares de novelas parecidas, provocando que el prisma feminista sea, hoy por hoy, el prominente de la distopía. Empero, el clásico de Atwood ha dado pie (le pasó y le pasa lo mismo al 1984 de Orwell) a usos menos reconfortantes. El 9 de junio de 2019, la influencer y multimillonaria Kylie Jenner organizó una fiesta temática de "El cuento de la criada" para celebrar el cumpleaños de la modelo Stassie Karanikolaou. Ataviadas con las conocidas túnicas rojas que visten por obligación las criadas de Gilead, las invitadas posaron sonrientes y compartieron las imágenes del evento en las redes sociales. La indignación no se hizo esperar. Pero eso es lo de menos. Lo relevante fue que el acto certificó el peligro de apropiación de la distopía crítica por parte del sistema, capaz, como ya sabían los teóricos frankfortianos de posguerra, de asimilar los discursos que le contradicen y evacuarlos en forma de mercancía reificada, inofensiva o, peor aún, colaboracionista (BACCOLINI 2020).

${ }^{14}$ Deseo, ciertamente, retroutópico, bañado de nostalgia, con pie y medio en un pasado idealizado. Claro está que la nostalgia no es privativa de los conservadores. Noticias de ninguna parte, clásico de la utopía socialista, rebosa de nostalgia medievalista, igual que Ecotopía, pilar de la utopía ecologista. 
Por si esto fuera poco, se suele pasar por alto que las distopías antifeministas (relatos acerca de futuros horrendos, pervertidos y totalitarios gobernados por mujeres que reducen a los hombres al rol de animal doméstico, mecanismo reproductor o parásito a liquidar) acompañaron a las dos primeras olas del feminismo. ${ }^{15}$ Igual que existen distopías antifeministas, las hay antiecologistas, como saben los lectores de Agenda 21 (BECK 20I2). España alumbró decenas de distopías contrarrevolucionarias durante las tres primeras décadas del siglo pasado, textos de hondo calado tradicionalista y católico que reflejaban el miedo de los conservadores patrios ante las conquistas e ímpetus revolucionarios de la clase obrera. ${ }^{16}$

\section{IX}

Los componentes utópicos de las distopias de última hornada no bastan para sustituir a la utopia estricta. Inmersa en la forma distópica, la esperanza social emite imágenes de resistencia y rebelión, no de civilizaciones alternativas, menester que le compete, por pura lógica, a la utopía. La distopía crítica filma revoluciones y apaga la cámara justo cuando vencen a la injusticia. Entonces, llega el fundido en blanco. Seguimos esperando a las utopías narrativas y teóricas que continúen el relato, que complementen la imprescindible crítica del presente con sugerencias imaginativas sobre cómo cambiarlo y crear un futuro más justo, conocedoras de que aunque el sufrimiento, el disenso y la insatisfacción siempre estarán ahí es posible hacer las cosas razonablemente mejor.

El campo filosóficamente relevante de la distopía es inmenso, y comprende enfoques y temas extremadamente variados. Los cinco artículos que

${ }^{15}$ Sobre esta cuestión es vital la web https://feminismo-cienciaficcion.org/tag/utopias-distopias/. La comedia de ciencia ficción Sexmission (Machulski 1984), rodada en los estertores de la Polonia comunista, lidera la producción cinematográfica de distopías antifeministas, corriente en la que medra la no menos inefable Si las mujeres mandaran (o mandasen) (GIRón I982). La distopía feminista Born in flames (Borden 1983) se proyectó entre ambas.

${ }^{16}$ Bajo el yugo de los bárbaros (LEón I932) es la distopía contrarrevolucionaria española por antonomasia. Empapado por el ambiente prebélico de la época, el autor intenta despertar la indignación de los lectores afines y ganar nuevos adeptos a la Cruzada contra la Bestia Roja novelando un futuro anarcocomunista en el que la familia, la religión y la propiedad han sido abolidas de sopetón; futuro uniformizado, masificado, desespiritualizado y analfabeto que destruye las máquinas del régimen burgués, censura la creación literaria e impone la bisexualidad, la eutanasia, la eugenesia, el nudismo y la vigilancia constante de los movimientos. 
conforman el presente monográfico ofrecen una aproximación multifacética al mismo.

David Sánchez Usanos entiende la distopía a modo de síntoma de una cultura embarrada, tiempo ha, en lo apocalíptico y la resignación, incapaz de forjar representaciones utópicas del futuro. Usanos pasa revista a diferentes manifestaciones de la cultura popular y registra la despolitización e individualización a la que se ve expuesta la indignación existente en la postmodernidad, reconfiguraciones que la vuelven inoperante para imprimir modificaciones sociales y desbaratar las sujeciones ideológicas de las que las distopías, y el resto de expresiones decadentistas que se han apoderado de la imaginación, brotan.

Anna Bugajska se sumerge, por su parte, en las discusiones bioéticas suscitadas por las tecnologías genómicas. Su artículo vuelve a certificar que la ciencia ficción en general y la distopía en particular son materiales analíticos muy potentes cuando de sondear la actualidad se trata. Tomando como hilo conductor la novela Next, de Michael Crichton, Bugajska presenta las principales problemáticas del debate genómico (autopropiedad, transparencia, big data), sus implicaciones biopolíticas y la necesidad de producir un paradigma utópico alrededor del particular que contraste con la visión tecnodistópica dominante y el tecnoutopismo, de suyo ingenuo, de corte neoliberal.

Ramón del Castillo ilumina la coexistencia de la distopía y la utopía tomando como vehículo Farenheit 451. El abordaje minucioso que practica del texto saca a la luz el inexplorado (o directamente tergiversado o mal interpretado por los analistas) utopismo de Bradbury gracias a la incorporación de datos biográficos y culturales tan relevantes como desconocidos por estos lares. Paralelamente, desbarata las interpretaciones habituales y reincidentes, conforme a las cuales Farenheit 451 promueve el desdén hacia la tecnología, el progreso y la ciudad, la defensa del elitismo cultural y el regreso a la naturaleza.

Lucas Misseri inspecciona la gestión del dilema libertad-felicidad en Nosotros y la compara con la efectuada por la ética kantiana y por el propio Zamiatin en otras obras. El artículo muestra que la civilización descrita en Nosotros legó a los distópicos sucesores las pautas para representar lo indeseable, identificado por anteponer, sin opción de mediación, la felicidad a la libertad, la ciencia a la ética. Misseri argumenta que libertad y felicidad constituyen una falsa dicotomía, circunstancia que repercute en la verosimilitud de la práctica totalidad del género distópico.

Cabe añadir, por último, que en la sección Brújula filosófica Elisabetta Di Minico ofrece una aproximación a la distopía desde una visión inversa a la que encontramos en la aportación de David Sánchez Usanos. A juicio de Di Minico, la distopía es un discurso insurrecto dotado de impulsos utópicos que analiza y rebate los sistemas de dominación, a la manera de la teoría crítica 
de Marcuse o Foucault. La autora escruta las heterogéneas modalidades del poder detalladas en los tres grandes referentes distópicos (Nosotros, Un mundo feliz y 1984) y diseña una mirada panorámica sobre cómo estos y otros títulos resultan indispensables a la hora de examinar, distinguir y reprobar los métodos coercitivos utilizados por el totalitarismo y la democracia, en especial los dirigidos al disciplinamiento de la corporalidad, las mujeres y los excluidos. 


\section{BIBLIOGRAFÍA}

Adorno, T. 2008, "Aldous Huxley y la utopía", Crítica de la cultura y sociedad I, Madrid: Akal, 85-107.

Aldridge, A. 1984, "The Scientific World View in Dystopia", Studies in Speculative Fiction, 3: 7-19.

Amis, K. 1960, New Maps of Hell. A Survey of Science Fiction, Nueva York: Harcourt Brace.

Baccolini, R. 2004, "The Persistence of Hope in Dystopian Science Fiction", PMLA, vol. 119, 3: 518-21.

Baccolini, R. 2020, "Hope isn't stupid: The Appropriaton of Dystopia", mediAzioni, 27: 39-49.

Balasopoulos, A. 20i I, "Anti-Utopia and Dystopia: Rethinking the Generic Field", V. Vlastaras (ed.), Utopia Project Archive, Athens: School of Fine Arts Publications, 59-67.

Bauman, Z. 20 Io, Miedo líquido. La sociedad contemporánea y sus temores, Barcelona: Paidós.

Berger, H. I976, Science Fiction and the New Dark Age, Ohio: Bowling University Press.

BLoch, E. 2004, El principio esperanza (vol. I), Madrid: Trotta.

Booker, K. I994, Dystopian Literature: A Theory and Research Guide, Connecticut: Greenwood Press.

Booker, K. I994, The Dystopian Impulse in Modern Literature. Fiction as Social Criticism, Connecticut: Greenwood Press.

Cioran, E. i98 I, Historia y utopía, México: Artífice 1981.

Cotarelo, R. i984, “Zamiatin, Huxley, Orwell: La Antiutopía”, C. G. Gual y R. Cotarelo (ed.), Orwell: 1984. Reflexiones desde 1984, Madrid: Espasa-Calpe, 107-33.

Domingo, A. 2008, Descenso literario a los infiernos demográficos. Distopía y población, Barcelona: Anagrama.

Eagleton, T. 20 io, "La utopía y sus opuestos", Minerva, 15: 52-7.

EAgleton, T. 20i6, Esperanza sin optimismo, Barcelona: Taurus.

Fisher, M. 20i6, Realismo capitalista. ¿No hay alternativa?, Buenos Aires: Caja Negra.

Fraser, N. 20 i 2, "Sobre la justicia. Lecciones de Platón, Rawls e Ishiguro", New Left Review, 74: 37-46.

Frye, N. 1982, "Diversidad de Utopías Literarias", F. Manuel (ed.), Utopías y pensamiento utópico, Madrid: Espasa-Calpe, 55-80.

GarCÉs, M. 2018, Nueva ilustración radical, Barcelona: Anagrama. 
Gasset, O. 1975, "Antiutopismo o antirracionalismo", El tema de nuestro tiempo, Madrid: Espasa-Calpe, 149-53.

Harvey, D. 2004, La condición de la posmodernidad. Investigación sobre los orígenes del cambio cultural, Buenos Aires: Amorrortu.

Harvey, D. 201 2, Espacios de esperanza, Madrid: Akal.

Herman, A. 1989, La idea de decadencia en la historia occidental, Barcelona: Andrés Bello.

Hillegas, M. 1967, The Future as Nightmare: H. G. Wells and the Anti-Utopians, New York: Oxford University Press.

Hinkelammert, F. 2002, Crítica de la razón utópica, Bilbao: Desclée.

Horkheimer, M. 2002, Critica de la razón instrumental, Madrid: Trotta.

Houellebece, M. 200 I, Las partículas elementales, Barcelona: Anagrama.

Jameson, F. 2000, Las semillas del tiempo, Madrid: Trotta.

Jameson, F. 2009, Arqueologías del futuro. El deseo llamado utopia y otras aproximaciones de ciencia ficción, Madrid: Akal.

Jameson, F. 20i6, "An American Utopia”, S. Zizex (ed.), An American Utopia. Dual Power and the Universal Army, London: Verso, 1-103.

Jonas, H. I994, El principio de responsabilidad. Ensayo de una ética para la civilización tecnológica, Barcelona: Círculo de Lectores.

Kant, I. I992, Filosofía de la historia, Madrid: Fondo de Cultura Económica.

Kumar, K. I998, "El apocalipsis, el milenio y la utopía en la actualidad”, M. BulL (comp.), La teoría del apocalipsis y los fines del mundo, México, D.F: Fondo de Cultura Económica, 233-60.

Kumar, K. 2000, "Utopia and Anti-Utopia in the Twentieth Century", L. SArgent y R, Schaer (ed.), Utopia: The Search for the Ideal Society in the Western World, New York: Oxford UP, 256-71.

Kumar, K. 2007, "Pensar utópicamente: política y literatura”, Revista Internacional de Filosofía Politica, 29: 65-80.

Kumar, K. 20io, "The Ends of Utopia”, New Literary History, vol. 41, 3: 549-69.

Ladeveze, L. I985, "De la utopía clásica a la distopía actual”, Revista de Estudios Politicos, 44: 47-80.

Lundway, S. I979, Historia de la ciencia ficción, Barcelona: Dronte.

Maddox, J. 1974, El sindrome del fin del mundo, Barcelona: Barral Editores.

MANning, L. 1976, El hombre que despertó en el futuro, Madrid: Edaf.

Martín, L. 20 I 8, El mundo feliz. Una apología de la vida falsa, Barcelona: Anagrama.

Milner, A. 2009, "Archaeologies of the Future: Jameson's Utopia or Orwell's Dystopia?", Historical Materialism, 17: 101-19.

Morton, A. i970, Las utopías socialistas, Barcelona: Martínez Roca.

Moylan, T. y Baccolini, R. (ed.). 2003, Dark Horizons: Science Fiction and the Dystopian Imagination, Londres: Routledge. 
Moylan, T. I986, Demand the Imposible: Science Fiction and the Utopian Imagination, Londres: Methuen.

Moylan, T. 2000, Scraps of the Untainted Sky. Science Fiction, Utopia, Dystopia, Oxford: Westview Press.

Mumford, L. I982, "La Utopía, la Ciudad y la Máquina”, F. Manuel (ed.), Utopías y pensamiento utópico, Madrid: Espasa-Calpe, 31-53.

RoRTy, R. I 994, ¿Esperanza o conocimiento? Una introducción al pragmatismo, Buenos Aires: Fondo de Cultura Económica.

SARgent, L. 2006, "In Defense of Utopia", Diógenes, 209: 11-1.

SARgent, L. 20I3, "Do Dystopias Matter”, F. Vieira (ed.), Dystopia(n) Matters: On the Page, on Screen, on Stage, London: Cambridge Scholars Publishing, $10-4$.

Seyferth, P. 201 8, "A Glimpse of Hope at the End of the Dystopian Century: The Utopian Dimensión of Critical Dystopias", ILCEA, 30:

Traverso, E. 2019, Melancolía de izquierdas. Después de las utopías, Barcelona: Gutenberg.

Trousson, R. I995, Historia de la literatura utópica, Barcelona: Península.

Vатtimo, G. I99 I, “Utopías, contrautopía, ironía”, Ética de la interpretación, Barcelona: Paidós, 95-112.

Vieira, F. 20io, "The concept of utopia", G. Claeys (ed.), Utopian Literature, Nueva York: Cambridge University Press, 3-27.

Walsh, C. 1962, From Utopia to Nightmare, New York: Harper \& Row.

ZIZEK, S. 2006, "Matrix, o las dos caras de la perversión”, Lacrimae rerum. Ensayos sobre cine moderno y ciberespacio, Barcelona: Debate.

ZizeK, S. 2009, Violencia. Seis reflexiones marginales, Barcelona: Paidós. 
Anna Bugajska es directora del Instituto de Lenguas Modernas y del Departamento de Estudios Lingüísticos y Culturales de la Universidad Jesuita Ignatianum de Cracovia. Colabora con el Departamento de Ética General y Aplicada de la misma universidad. Es miembro de Utopian Studies Society - Europe y colaboradora de International Society for Clinical Bioethics. Está interesada en la ficción distópica, la bioética y la filosofía de la ciencia y la tecnología. Entre sus publicaciones destacan, entre otras, los artículos "Sobre la posibilidad de una ética poshumana", "The Future of Education in the Context of Cognitive Enhancement" y "Dystopian Solutions to Immigration", y el libro Engineering Youth: the Evantropian Project in Young Adult Dystopias (Ignatianum University Press, 2019), donde investiga problemas relacionados con el desarrollo biotecnológico y el pensamiento utópico.

Ramón del Castillo (Madrid, 1964) es profesor titular y vicedecano de investigación y doctorado en la Facultad de Filosofía y Antropología de la UNED. Desde 1995 desarrolla una amplia actividad como historiador de las ideas y ha publicado numerosos trabajos sobre filosofía angloamericana, especialmente de la tradición socialista de inspiración hegeliana. Fue editor y traductor de obras de John Dewey, William James, Terry Eagleton, Fredric Jameson y Richard Rorty. Entre sus trabajos destacan: "Érase una vez América", "Espectros del idealismo", "Estetas y profetas", "En el nombre del materialismo", "Un filósofo con mano izquierda” y "Gags and Games. Wittgenstein and his Relation to Jokes". En los últimos años ha investigado las dimensiones políticas del urbanismo y las ideologías de la Naturaleza. Algunas de sus publicaciones más recientes: "La corrosión de la experiencia: populismo, abstracción y cultura de masas" (2018), El jardin de los delirios. Las ilusiones del naturalismo (Turner, 2019), Filósofos de paseo (Turner, 2020) y "Del espacio exterior al espacio interior: Raymond Williams y la ciencia-ficción” (202 I).

Elisabetta Di Minico, es doctora Cum Laude y Mención Internacional en Historia Contemporánea. Enseña Historia del Cómic en la IULM de Milán, y forma parte del grupo de investigación HISTOPIA, coordinado por la Universidad Autónoma de Madrid. Es “cultricedella materia” en Literatura Italiana en la Università degli Studi Suor Orso la Benincasa de Nápoles. Se ocupa principalmente de distopía, control, alteridad y violencia (racial y de género). Utiliza novelas, cómics, películas y series para analizar los "malos lugares" reales de la sociedad contemporánea. Entre sus publicaciones, destacan el libro $\mathrm{Il}$ futuro in bilico (Meltemi, 2018), los capítulos "Utopía y distopía del cuerpo femenino" (en Lugares de utopia, Polifemo, 2019) y "X-Men Saga and the Dystopian Otherness" (en Utopia and Dystopia in the Age of Trump, Dickinson 
University Press, 2019), y el artículo "Spatial, linguistic and psycho-physical domination of women in dystopia: Swastika Night, Woman on the Edge of Time and The Handmaid's Tale" (en Humanities 8, 2019).

Lucas E. Misseri. Profesor visitante en el Departamento de Filosofía del Derecho de la Universidad de Alicante (2018-2021). Doctor en Filosofía por la Universidad Nacional de Lanús (2013), con una tesis —adaptada y publicada como Utopismo, Responsabilidad y Convergencia (2017) - en la que se hace una revisión de utopías literarias occidentales a la luz de las teorías de R. Maliandi y H. Jonas. Ha sido investigador del Centro de Investigaciones Jurídicas y Sociales de la Universidad Nacional de Córdoba (Argentina) y director de la revista Prometeica. Asimismo, ha realizado estancias de investigación en Eslovaquia (2009), México (2010), Australia (2013) y Bélgica (2016). Sus áreas de interés son la filosofía práctica (principalmente ética, derecho y política) y la historia de la filosofía. Sobre esos temas ha publicado una veintena de artículos en revistas académicas en español, inglés y eslovaco, y editado varios monográficos.

David Sánchez Usanos es profesor de filosofía en la UAM y director académico de SUR, Escuela de Profesiones Artísticas (Círculo de Bellas Artes de Madrid). En el pasado compaginó su actividad docente e investigadora con la crítica literaria y musical. Ha sido investigador visitante en Cornell University (Ithaca, Nueva York). Entre sus numerosas publicaciones destacan los artículos "Error del sistema", "Marxismo y posmodernismo" y "Nota sobre la revolución", además del libro $A$ tres versos del final. Filosofía y literatura (Siglo $\mathrm{xxI}$ ). Ha realizado la introducción, traducción y notas de Las variaciones sobre Hegel. Sobre la Fenomenología del Espiritu (Akal) y de los Ensayos y discursos de William Faulkner (Capitán Swing), así como la edición de El postmodernismo revisado, de Fredric Jameson (Abada). Junto a este último ha publicado, además, Reflexiones sobre la postmodernidad (Abada). 
